\section{Intravitreal Triamcinolone Acetonide Therapy in Diabetic Macular Edema - Evaluation of the Effects of Metabolic Control, Serum Inflammatory Markers and Endothelial} Factors

\author{
Márcia S Queiroz ${ }^{1 *}$, Fábio P Saraiva ${ }^{2}$, Roni C Preti ${ }^{2}$, Rosa T \\ Fukui $^{3}$, Walter $Y$ Takahashi $^{2}$, Márcia Nery ${ }^{1}$ and Maria \\ Elizabeth R Silva ${ }^{1,3}$
}

${ }^{1}$ Diabetes Unit, Endocrine Service of Hospital das Clinicas, University of São Paulo Medical School, São Paulo, Brazil

${ }^{2}$ Department of Ophthalmology, Hospital das Clinicas, University of São Paulo Medical School, São Paulo, Brazil

${ }^{3}$ Laboratory of Medical Investigation, University of São Paulo Medical School, São Paulo, Brazil

\begin{abstract}
The exact pathogenesis of retinopathy in diabetic individuals is not yet fully understood, but may involve chronic low-grade inflammation and dysfunction of the vascular endothelium. Intravitreal Triamcinolone Acetonide (IVTA) has been considered safe and effective to treat diabetic macular edema. The aim of this study was to evaluate the short and long term effects of IVTA injection on serum factors associated with inflammation and endothelial dysfunction, on diabetes control, and the relationship of these markers with changes in visual acuity after IVTA therapy. This study involved 15 patients with type 2 diabetes evaluated at the Hospital das Clinicas of University of São Paulo medical school. The levels of $C$-reactive protein, fibrinogen, soluble intercellular adhesion molecule-1, interleukin-6, vascular endothelial growth factor, tumor necrosis factor- alpha, transforming growth factor- beta 1 and insulin-like growth factor-1 were assessed at baseline and after IVTA injection. The levels of serum factors associated with inflammation and endothelial dysfunction did not change significantly and were not correlated with grade of retinopathy or changes in macular
\end{abstract}

*Corresponding author: Márcia S Queiroz, Diabetes Unit, Endocrine Service of Hospital das Clinicas, University of São Paulo Medical School, Cerqueira César, São Paulo, Brazil, E-mail: fabiopetersen@yahoo.com.br

Citation: Queiroz MS, Saraiva FP, Preti RC, Fukui RT, Takahashi WY, et al. (2016) Intravitreal Triamcinolone Acetonide Therapy in Diabetic Macular Edema - Evaluation of the Effects of Metabolic Control, Serum Inflammatory Markers and Endothelial Factors. J Diabetes Metab Disord 3: 008.

Received: February 22, 2016; Accepted: February 27, 2016; Published: March 14,2016 edema and visual acuity after IVTA therapy. This study suggests that IVTA injections diabetic patients with retinopathy did not interfere with glucose control, blood inflammatory factors or markers of endothelial dysfunction.

\section{Introduction}

Proliferative Diabetic Retinopathy (DR) and Diabetic Macular Edema (DME) are leading causes of blindness among working-age populations [1]. Advanced stages of DR are characterized by the growth of abnormal retinal blood vessels secondary to ischemia in an attempt to supply oxygenated blood to the hypoxic retina. Patients with diabetes can also develop DME at any time during the progression of DR, which involves retinal thickening in the macular area. DME occurs after breakdown of the Blood-Retinal Barrier (BRB) as a result of dilated hyper permeable capillary leakage and microaneurysms [2].

Several biochemical pathways have been proposed linking hyperglycemia and microvascular complications. These include accumulation of intracellular sorbitol, formation of Advanced Glycation End products (AGEs), oxidative stress, and activation of Protein Kinase C- $\beta$ (PKC- $\beta$ ). These pathological pathways are thought to modulate the disease process through effects on cellular metabolism, signaling, and growth factors [3]. Inflammation and endothelial dysfunction are also mechanisms that may play an important role in the etiology of diabetic retinopathy. Increased levels of inflammation and endothelial dysfunction markers such as C-Reactive Protein (CRP), Fibrinogen (FIB), Interleukin-6 (IL-6), Tumor Necrosis Factor-alpha (TNF- $\alpha$ ), Vascular Endothelial Growth Factors (VEGF), Growth Hormone, Insulin-like Growth Factor-I (IGF-I), Transforming Growth Factor- $\beta$ (TGF- $\beta$ ), soluble Intercellular Adhesion Molecule-1 (sICAM), and soluble Vascular Cell Adhesion Molecule-1 (sVCAM) [4-9] have been associated with development of microalbuminuria [10-12], which itself is strongly associated with retinopathy in type 1 and type 2 diabetes [13]. Also high levels of the 2 latter markers have been reported in subjects with retinopathy $[8,9,14,15]$.

Opposite effects have been linked to corticosteroids which reduce the breakdown of the blood-retinal barrier, decrease inflammation, and down-regulate the production of vascular endothelial growth factor [16,17]. The use of Intravitreal Triamcinolone Acetonide (IVTA) has increased in the last 7 years after reports of successful treatment of macular edema secondary to diabetes, uveitis, and central retinal vein $[10,18-22]$.

However, no study to date has reported the effects of IVTA on blood glucose and inflammatory marker levels or their relationship with improvements in macular edema. Our study is the first of its kind to report the short (7 days) and long term (30 days) effects of IVTA on diabetes control and on the serum factors associated with inflammation and endothelial dysfunction (CRP, fibrinogen, interleukin-6, sICAM, VEGF, TNF- $\alpha$ and TGF- $\beta$ and) in type 2 diabetes patients with prevalent moderate or severe diabetic retinopathy. 


\section{Patients}

This study involved 15 type 2 diabetes patients $(9$ men and 6 women) presenting diffuse macular edema, regularly attending the Ophthalmologic Service of Hospital das Clinicas of the São Paulo University medical school. All patients first underwent follow-up with a diabetes specialist for $2.3 \pm 1.7$ months until achieving metabolic control, characterized by fasting blood glucose levels $<150 \mathrm{mg} / \mathrm{dL}$ and $\mathrm{HbA} 1 \mathrm{c}<7.5 \%$. Subsequently, the patients were evaluated and treated by a single fellowship-trained retina specialist. A full ocular examination including best corrected visual acuity, slit lamp biomicroscopy, tonometry, dilated ophthalmoscopy, and Optical Coherence Tomography (OCT; Stratus OCT ${ }^{\mathrm{TM}}$ model 3000, version 4.0.1, Carl zeiss Meditec Inc. Dublin, CA) was performed. Also, the level of retinopathy was graded as moderate or severe, proliferative or non proliferative, and the level of macular edema defined according to the early treatment diabetic retinopathy study [23].

The following exclusion criteria were adopted: chronic renal disease (serum creatinine $>1.5 \mathrm{mg} / \mathrm{dl}$ ), uncontrolled arterial hypertension ( $\mathrm{PA}>150 \times 90 \mathrm{mmHg}$ ), high blood glucose levels (fasting glucose $>150 \mathrm{mg} / \mathrm{dl}$ and $\mathrm{HbAlc}>7.5 \%$ ), and any severe concomitant illness. Patients using antihypertensive or lipid-lowering agents were not excluded, but the doses of these medications were kept stable throughout the study protocol. The study was approved by the Ethics Committee of Hospital das Clinicas of the University of São Paulo medical school and all participants gave written informed consent. Nine out of 15 patients were submitted to photocoagulation 3 to 4 months prior to IVTA treatment.

\section{Methods}

Patients' fasting serum was ascertained at three different times (baseline, and on days 7 and 30 after $4 \mathrm{mg}$ of IVTA) in order to assess the blood levels of C-Reactive Protein (CRP), fibrinogen, soluble Intercellular Adhesion Molecule-1 (sICAM-1), interleukin-6 (IL-6), Vascular Endothelial Growth Factor (VEGF), TNF alpha, TGF beta 1, Insulin-like Growth Factor-I (IGF-1), and to provide a biochemical profile.

HbAlc (normal range 4-6\%) was determined in whole blood using ion-exchange High-Performance Liquid Chromatography (HPLC). Fibrinogen was determined by a functional method [24]. The Enzyme-Linked Immunosorbent Assay (ELISA) method was used to measure Interleukin-6 (IL-6), sICAM, VEGF, TNF- $\alpha$ and TNF- $\beta$ (R\&D Systems), while high sensitive CRP (Behring) and IGF-1 (Diagnostic Systems Laboratories, Inc. Webster, Texas) were measured by radioimmunoassay. Other biochemical analyses were carried out using commercial kits, as part of the routine assessment at the Central Laboratory of the Hospital das Clinicas.

\section{Statistical Analyses}

The Graph Pad Prism Program version 4.0 for personal computers was used for the statistical analysis. Results are presented as means \pm SD, while changes in sICAM-1, TGF- $\alpha$, TGF- $\beta$, fibrinogen, CRP, IL-6, VEGF, HbAlc, and glycemia from baseline to $7^{\text {th }}$ and $30^{\text {th }}$ day after $4 \mathrm{mg}$ IVTA injections were compared using the one-way analysis of variance.

(ANOVA) followed by Bonferroni's test or Bartlett's test. The unpaired $t$ test was used to compare differences between moderate and severe non-proliferative DR groups for all inflammation and endothelial variables studied. A P value $\leq 0.05$ was considered statistically significant.

\section{Results}

Severe non-proliferative DR was present in 8 patients, and moderate non-proliferative observed in another 7 subjects. Prior treatment with panretinal photocoagulation was noted in 9 individuals. The clinical characteristics and biochemical profile of the subjects are shown in table 1 .

\begin{tabular}{|c|c|c|c|c|}
\hline & Baseline & $\begin{array}{l}7^{7^{\text {th }}} \text { day } \\
\text { after IVTA } \\
\text { injection }\end{array}$ & $\begin{array}{l}30^{\text {th }} \text { IVTA } \\
\text { injection }\end{array}$ & $\begin{array}{c}\text { Statistical } \\
\text { Analysis }\end{array}$ \\
\hline $\begin{array}{l}\text { Number of } \\
\text { patients }\end{array}$ & 15 & & & \\
\hline Age (years) & $63.8 \pm 8.2$ & & & \\
\hline Gender (M/F) & 6-Sep & & & \\
\hline $\begin{array}{l}\text { Duration of dia- } \\
\text { betes (years) }\end{array}$ & $14.6 \pm 8.3$ & & & \\
\hline $\begin{array}{l}\text { Fasting glu- } \\
\text { cose (mg/dL) }\end{array}$ & $126.7 \pm 32.6$ & $146.4 \pm 41.8$ & $156.6 \pm 68.3$ & $\mathrm{p}=0.4458$ \\
\hline $\begin{array}{c}\text { Total cholester- } \\
\text { ol (mg/dL) }\end{array}$ & $196.5 \pm 49.1$ & $201.2 \pm 50.7$ & $188.4 \pm 46$ & $p=0.4361$ \\
\hline $\begin{array}{l}\text { LDL cholesterol } \\
(\mathrm{mg} / \mathrm{dL})\end{array}$ & $115.9 \pm 50$ & $122.7 \pm 44.5$ & $111.4 \pm 41.1$ & $p=0.4750$ \\
\hline $\begin{array}{l}\text { Triglyceride } \\
(\mathrm{mg} / \mathrm{dL})\end{array}$ & $142.1 \pm 71.8$ & $148.6 \pm 63.4$ & $156 \pm 65.7$ & $p=0.4268$ \\
\hline $\mathrm{HbA} 1 \mathrm{c}$ & $6.63 \pm 0.84$ & $6.93 \pm 1.07$ & $6.95 \pm 1.39$ & $p=0.4831$ \\
\hline
\end{tabular}

Table 1: Clinical and biochemical characteristics of type 2 diabetes patients enrolled in the study.

IVTA injection had no influence on metabolic parameters (fasting blood glucose, HbAlc, total-cholesterol, LDL-c and triglycerides levels), which remained similar at baseline, day 7 and day 30 .

Fibrinogen levels were slightly lower 7 and 30 days after IVTA, but this difference did not reach statistical significance, $\mathrm{p}=0.05$ (Figure1).

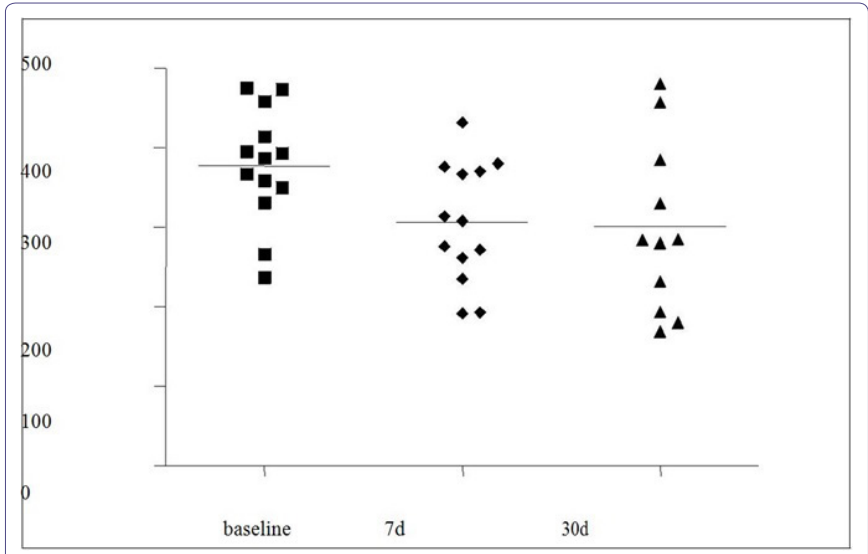

Figure 1: Plasma fibrinogen levels at baseline, 7 days and 30 days after IVTA injection.

Fibrinogen: $\mathrm{mg} / \mathrm{dL} ; \mathrm{P}=0.05$ for baseline versus 7 days $(7 \mathrm{~d})$, and baseline versus 30 days (30d).

Levels of CRP, another marker of endothelial dysfunction, together with inflammatory markers -TNF- $\alpha$, IL-6, sICAM-1, VEGF, TNF alpha, TGF beta 1, IGF-1 did not change short or long term after IVTA injection (Table 2). 


\begin{tabular}{|c|c|c|c|}
\hline & Baseline & $\begin{array}{c}\mathbf{7}^{\text {th }} \text { day after IVTA } \\
\text { injection }\end{array}$ & $\begin{array}{c}\mathbf{3 0}^{\text {th }} \text { day after } \\
\text { IVTA injection }\end{array}$ \\
\hline TNF- $\alpha(\mathrm{pg} / \mathrm{dL})$ & $1.89 \pm 0.82$ & $1.98 \pm 0.81$ & $1.79 \pm 0.77$ \\
\hline IL-6 $(\mathrm{pg} / \mathrm{mL})$ & $2.62 \pm 2.18$ & $2.72 \pm 1.7$ & $3.06 \pm 2.0$ \\
\hline VEGF $(\mathrm{pg} / \mathrm{mL})$ & $280.2 \pm 172.6$ & $287.4 \pm 168.7$ & $276 \pm 175.6$ \\
\hline IGF-I $(\mathrm{ng} / \mathrm{mL})$ & $175.7 \pm 104.1$ & $120.3 \pm 67.6$ & $142.7 \pm 72$ \\
\hline TGF- $\beta(\mathrm{ng} / \mathrm{dL})$ & $31.2 \pm 6.8$ & $30.2 \pm 6.4$ & $32.6 \pm 8.6$ \\
\hline sICAM $(\mathrm{ng} / \mathrm{mL})$ & $204.2 \pm 73.4$ & $204.9 \pm 75.8$ & $203.1 \pm 76.7$ \\
\hline
\end{tabular}

Table 2: Evolution of markers of inflammation and endothelial dysfunction after Intravitreal Triamcinolone Acetonide (IVTA) injection.

Data are means $\pm S D$

Four out of nine patients submitted to photocoagulation associated to IVTA, experienced a 10 or more letter improvement in visual acuity (44\%) 4 months after IVTA, while only 2 patients treated exclusively with IVTA presented this improvement (33\%). The gain in visual acuity was maintained after 6 months of follow-up. There was also a substantial reduction in central macular thickness after 30 days of IVTA treatment, with thickness decreasing significantly from $0.356 \pm 0.06 \mu \mathrm{m}$ to $0.236 \pm 0.05 \mu \mathrm{m}$ in a group that was treated using previous photocoagulation plus IVTA, and from $0.352 \pm 0.09 \mu \mathrm{m}$ to $0.236 \pm 0.04 \mu \mathrm{m}$ in patients treated exclusively with IVTA.

However, none of the inflammatory and endothelial dysfunction markers analyzed were significantly correlated with level of retinopathy, previous photocoagulation procedure, IVTA injection, improvement in visual acuity or decrease in macular thickness $(\mathrm{P}>0.05$ for all analyses; data not shown).

\section{Discussion}

This study evaluated the effect of intravitreal triamcinolone acetonide on diabetes control, levels of serum inflammatory factors and markers of endothelial dysfunction in patients with type 2 diabetes, and also the relationship of these markers with macular edema and improvement in visual acuity was also investigated.

As the mean elimination half-life of intravitreous triamcinolone was reported to be 18.6 days in non-vitrectomized patients [25], we analyzed the patients at 7 and 30 days after a single dose of IVTA, in order to evaluate acute and long term effects of the drug. No difference was demonstrated in metabolic parameters such as fasting glucose, total and LDL-cholesterol and HbA1c levels, highlighting that low doses of topic glucocorticoids did not interfere with glucose and lipid control.

Retinopathy is also associated with low-grade chronic inflammation $[26,27]$. It has been hypothesized that VEGF, a key mediator of angiogenesis in the retina, can trigger early retinal inflammation by inducing the expression and upregulation of sICAM-1. The increase in adhesion molecules facilitates leukocyte adhesion and stasis in the retinal vasculature, and an increase in permeability of the endothelium, which may be the initial step in the complex pathology of retinopathy [28-30].

Previous studies have shown higher inflammatory activity in individuals with type 1 or type 2 diabetes than in their non-diabetic peers [31,32], associated with macrovascular disease and microangiopathy. Although corticosteroids have been used in ophthalmology for decades to suppress intraocular inflammation and reduce extravasations from blood vessels, it has yet to be established exactly how the corticosteroids reduce macular edema. Several theories have been proposed, including local reduction of inflammatory mediators [33], increased diffusion of calmodulin by an effect on calcium channels [34], decrease in vascular endothelial growth factors levels [35], and improvement of blood-retinal barrier function [17].

Our results showed that two important markers of endothelial dysfunction (fibrinogen and CRP) did not correlate with previous levels of retinopathy, photocoagulation nor IVTA therapy. Moreover, the levels of inflammatory markers VEGF, IGF-1, TGF- $\beta$, TNF- $\alpha$, IL-6 and sICAM were not correlated with improvement in visual acuity after IVTA injection. Other studies have associated the increased sera levels of sVCAM with diabetic retinopathy [8] and nephropathy [15]. Doganay et al., [36] demonstrated that TNF- $\alpha$ level in the serum of patients with Proliferative Diabetic Retinopathy (PDR) was higher than in patients with Non-Proliferative Diabetic Retinopathy (NPDR), Non-Diabetic Retinopathy (NDR) and controls. Perhaps, we did not observe a graded level of these markers because only patients with severe retinal damage were included.

It has been suggested that hyperglycemia may lead to the activation of proinflammatory cytokines that are crucial for development and progression of retinopathy $[37,38]$. These cytokines are involved in BRB breakdown by opening tight junctions of retinal vascular endothelial cells and pigmented epithelial cells which participate in DME $[39,40]$. Decline in the elevated IL-6 levels in human peripheral monocytes of patients with poorly controlled DM has been demonstrated after normalization of plasma glucose [41]. However, circulating plasma VEGF concentrations were not strongly correlated with risk factor status or microvascular disease in type 1 diabetes in the EUCLID study [42]. Therefore, increased production of local VEGF and other endothelial or inflammatory markers in ocular fluid [5], not reflected by an increase in their levels circulating in plasma, could explain these discrepancies. Fibrinogen levels, related to inflammatory status and incidence of retinopathy $[43,44]$, were slightly lower 7 days and 30 days after IVTA $(p=0.05)$, whereas C-reactive protein levels did not change.

Improvements in visual acuity, akin to those observed by other authors [45-47], were found in 4 patients submitted to photocoagulation and IVTA at 1 month of follow-up, but these results did not correlate with the level of inflammatory and endothelial markers or glycemic control.

It is likely that no significant change in the levels of these inflammatory markers was observed because the patients enrolled in this study had already reached good and stable metabolic control before IVTA treatment. Changes in serum concentrations of cytokines have been shown to be associated with long-term metabolic control parameters, such as $\mathrm{HbAlc}$ and fructosamine for glycemic control, and HDL cholesterol for triglyceride metabolism, and lipid peroxidation [48,49]. Chiarelli et al., [43] reported an improvement in the elevated plasma VEGF level in diabetic children and adolescents with poor glycemic control (HbAlc $>10 \%)$ after 2 years of tight metabolic control ( $\mathrm{HbAlc}<7 \%)$, suggesting the possible influence of long-term glycemic control on this serum marker level. The mean level of HbAlc in our patients (6.6\%) was very stable in the present study compared to levels observed by other authors, reflecting extremely tight metabolic control. This stability in glucose control could be another reason for the lack of change in these endothelial markers in relation to hyperglycemia.

Corticosteroids are known to reduce intraocular inflammation and, depending on their concentration, to suppress proliferation of 
cells, thereby contributing to improvement in visual acuity and reduced macular thickness [44]. The present study suggests that a $4 \mathrm{mg}$ IVTA injection in type 2 diabetic patients with retinopathy did not interfere with glucose control, blood inflammatory factors or markers of endothelial dysfunction, and showed that this therapy was associated with improvement in visual acuity in 6 out of 15 type 2 diabetes patients.

\section{References}

1. Kempen JH, O'Colmain BJ, Leske MC, Haffner SM, Klein R, et al. (2004) The prevalence of diabetic retinopathy among adults in the United States. Arch Ophthalmol 122: 552-563.

2. Ciulla TA, Amador AG, Zinman B (2003) Diabetic retinopathy and diabetic macular edema: pathophysiology, screening, and novel therapies. Diabetes Care 26: 2653-2664.

3. Fong DS, Aiello LP, Ferris FL 3rd, Klein R (2004) Diabetic retinopathy. Diabetes Care 27: 2540-2553.

4. Stehouwer CD, Lambert J, Donker AJ, van Hinsbergh VW (1997) Endothelia dysfunction and pathogenesis of diabetic angiopathy. Cardiovasc Res 34 $55-68$.

5. Aiello LP, Avery RL, Arrigg PG, Keyt BA, Jampel HD, et al. (1994) Vascular endothelial growth factor in ocular fluid of patients with diabetic retinopathy and other retinal disorders. N Engl J Med 331: 1480-1487.

6. Miller JW, Adamis AP, Aiello LP (1997) Vascular endothelial growth factor in ocular neovascularization and proliferative diabetic retinopathy. Diabetes Metab Rev 13: 37-50.

7. Xia P, Aiello LP, Ishii H, Jiang ZY, Park DJ, et al. (1996) Characterization of vascular endothelial growth factor's effect on the activation of protein kinase C, its isoforms, and endothelial cell growth. J Clin Invest 98: 2018-2026.

8. Fasching P, Veitl M, Rohac M, Streli C, Schneider B, et al. (1996) Elevated concentrations of circulating adhesion molecules and their association with microvascular complications in insulin-dependent diabetes mellitus. J Clin Endocrinol Metab 81: 4313-4317.

9. Matsumoto K, Sera Y, Ueki Y, Inukai G, Niiro E, et al. (2002) Comparison of serum concentrations of soluble adhesion molecules in diabetic microangiopathy and macroangiopathy. Diabet Med 19: 822-826.

10. Challa JK, Gillies MC, Penfold PL, Gyory JF, Hunyor AB, et al. (1998) Exudative macular degeneration and intravitreal triamcinolone: 18 month follow up. Aust N Z J Ophthalmol 26: 277-281.

11. Jager A, van Hinsbergh VW, Kostense PJ, Emeis JJ, Nijpels G, et al. (2002) $\mathrm{C}$-reactive protein and soluble vascular cell adhesion molecule-1 are associated with elevated urinary albumin excretion but do not explain its link with cardiovascular risk. Arterioscler Thromb Vasc Biol 22: 593-598.

12. Stehouwer CD, Gall MA, Twisk JW, Knudsen E, Emeis JJ, et al. (2002) Increased urinary albumin excretion, endothelial dysfunction, and chronic lowgrade inflammation in type 2 diabetes: progressive, interrelated, and independently associated with risk of death. Diabetes 51: 1157-1165.

13. Crimi S, Cipolli D, Infantone E, Infantone L, Lunetta M (1995) Microalbuminuria and severity of diabetic retinopathy in type 1 diabetic patients: association and relationship with some risk factors. Diabete Metab 21: 440-445.

14. Wirta O, Pasternack A, Mustonen J, Laippala P, Lähde Y (1999) Retinopathy is independently related to microalbuminuria in type 2 diabetes mellitus. Clin Nephrol 51: 329-334.

15. Koga M, Otsuki M, Kubo M, Hashimoto J, Kasayama S (1998) Relationship between circulating vascular cell adhesion molecule-1 and microvascular complications in type 2 diabetes mellitus. Diabet Med 15: 661-667.

16. Ozaki NK, Beharry KD, Nishihara KC, Akmal Y, Ang JG, et al. (2002) Regulation of retinal vascular endothelial growth factor and receptors in rabbits exposed to hyperoxia. Invest Ophthalmol Vis Sci 43:1546-1557.
17. Wilson CA, Berkowitz BA, Sato Y, Ando N, Handa JT, et al. (1992) Treatment with intravitreal steroid reduces blood-retinal barrier breakdown due to retinal photocoagulation. Arch Ophthalmol 110: 1155-1159.

18. Mohamed Q, Gillies MC, Wong TY (2007) Management of diabetic retinopathy: a systematic review. JAMA 298: 902-916.

19. Jonas JB, Hayler JK, Panda-Jonas S (2000) Intravitreal injection of crystalline cortisone as adjunctive treatment of proliferative vitreoretinopathy. $\mathrm{Br} \mathrm{J}$ Ophthalmol 84: 1064-1067.

20. Jonas JB, Kreissig I, Söfker A, Degenring RF (2003) Intravitreal injection of triamcinolone for diffuse diabetic macular edema. Arch Ophthalmol 121: 57 61

21. Martidis A, Duker JS, Greenberg PB, Rogers AH, Puliafito CA, et al. (2002) Intravitreal triamcinolone for refractory diabetic macular edema. Ophthalmology 109: 920-927.

22. Penfold PL (2002) Intravitreal triamcinolone in recurrence of choroidal neovascularisation. $\mathrm{Br} \mathrm{J}$ Ophthalmol 86: 600-601.

23. [No authors listed] (1991) Grading diabetic retinopathy from stereoscopic color fundus photographs--an extension of the modified Airlie House classification. ETDRS report number 10. Early Treatment Diabetic Retinopathy Study Research Group. Ophthalmology 98: 786-806.

24. Clauss A (1957) [Rapid physiological coagulation method in determination of fibrinogen]. Acta Haematol 17: 237-246.

25. Beer PM, Bakri SJ, Singh RJ, Liu W, Peters GB 3rd, et al. (2003) Intraocular concentration and pharmacokinetics of triamcinolone acetonide after a single intravitreal injection. Ophthalmology 110: 681-686.

26. Adamis AP (2002) Is diabetic retinopathy an inflammatory disease? $\mathrm{Br} \mathrm{J}$ Ophthalmol 86: 363-365.

27. Gardner TW, Antonetti DA, Barber AJ, LaNoue KF, Levison SW (2002) Diabetic retinopathy: more than meets the eye. Surv Ophthalmol 2: 253-262.

28. Joussen AM, Poulaki V, Qin W, Kirchhof B, Mitsiades N, et al. (2002) Retinal vascular endothelial growth factor induces intercellular adhesion molecule-1 and endothelial nitric oxide synthase expression and initiates early diabetic retinal leukocyte adhesion in vivo. Am J Pathol 160: 501-509.

29. Barouch FC, Miyamoto K, Allport JR, Fujita K, Bursell SE, et al. (2000) Integrin-mediated neutrophil adhesion and retinal leukostasis in diabetes. Invest Ophthalmol Vis Sci 41: 1153-1158.

30. Olson JA, Whitelaw CM, McHardy KC, Pearson DW, Forrester JV (1997) Soluble leucocyte adhesion molecules in diabetic retinopathy stimulate retinal capillary endothelial cell migration. Diabetologia 40: 1166-1171.

31. Kado S, Nagata N (1999) Circulating intercellular adhesion molecule-1, vascular cell adhesion molecule-1, and E-selectin in patients with type 2 diabetes mellitus. Diabetes Res Clin Pract 46: 143-148.

32. Schalkwijk CG, Poland DC, van Dijk W, Kok A, Emeis JJ, et al. (1999) Plasma concentration of $\mathrm{C}$-reactive protein is increased in type I diabetic patients without clinical macroangiopathy and correlates with markers of endothelial dysfunction: evidence for chronic inflammation. Diabetologia 42: 351-357.

33. Kang BS, Chung EY, Yun YP, Lee MK, Lee YR, et al. (2001) Inhibitory effects of anti-inflammatory drugs on interleukin-6 bioactivity. Biol Pharm Bull 24: 701-703.

34. Sze PY, Iqbal Z (1994) Glucocorticoid action on depolarization-dependent calcium influx in brain synaptosomes. Neuroendocrinology 59: 457-465.

35. Bandi N, Kompella UB (2001) Budesonide reduces vascular endothelial growth factor secretion and expression in airway (Calu-1) and Alveolar (A549) epithelial cells. Eur J Pharmacol 425: 109-116.

36. Doganay S, Evereklioglu C, Er H, Türköz Y, Sevinç A, et al. (2002) Comparison of serum NO, TNF-alpha, IL-1beta, sIL-2R, IL-6 and IL-8 levels with grades of retinopathy in patients with diabetes mellitus. Eye (Lond) 16: 163170.

37. McCarter RJ, Hempe JM, Gomez R, Chalew SA (2004) Biological variation in $\mathrm{HbA} 1 \mathrm{c}$ predicts risk of retinopathy and nephropathy in type 1 diabetes. Diabetes Care 27: 1259-1264. 
38. Myśliwiec M, Balcerska A, Zorena K, Myśliwska J, Lipowski P, et al. (2008) The role of vascular endothelial growth factor, tumor necrosis factor alpha and interleukin- 6 in pathogenesis of diabetic retinopathy. Diabetes Res Clin Pract 79: 141-146.

39. de Vos AF, van Haren MA, Verhagen C, Hoekzema R, Kijlstra A (1994) Kinetics of intraocular tumor necrosis factor and interleukin- 6 in endotoxin-induced uveitis in the rat. Invest Ophthalmol Vis Sci 35: 1100-1106.

40. Yokoi M, Yamagishi SI, Takeuchi M, Ohgami K, Okamoto T, et al. (2005) Elevations of AGE and vascular endothelial growth factor with decreased total antioxidant status in the vitreous fluid of diabetic patients with retinopathy. $\mathrm{Br}$ J Ophthalmol 89: 673-675.

41. Morohoshi M, Fujisawa K, Uchimura I, Numano F (1996) Glucose-dependen interleukin 6 and tumor necrosis factor production by human peripheral blood monocytes in vitro. Diabetes 45: 954-959.

42. Chaturvedi N, Fuller JH, Pokras F, Rottiers R, Papazoglou N, et al. (2001) Circulating plasma vascular endothelial growth factor and microvascular complications of type 1 diabetes mellitus: the influence of ACE inhibition. Diabet Med 18: 288-294.

43. Chiarelli F, Spagnoli A, Basciani F, Tumini S, Mezzetti A, et al. (2000) Vas cular Endothelial Growth Factor (VEGF) in children, adolescents and young adults with Type 1 diabetes mellitus: relation to glycaemic control and microvascular complications. Diabet Med 17: 650-656.
44. Kuppermann BD, Blumenkranz MS, Haller JA, Williams GA, Weinberg DV, et al. (2007) Randomized controlled study of an intravitreous dexamethasone drug delivery system in patients with persistent macular edema. Arch Ophthalmol 125: 309-317.

45. Bakri SJ, Beer PM (2004) Intravitreal triamcinolone injection for diabetic macular edema: a clinical and fluorescein angiographic case series. Can J Ophthalmol 39: 755-760.

46. Karacorlu M, Ozdemir H, Karacorlu S, Alacali N, Mudun B, et al. (2005) Intravitreal triamcinolone as a primary therapy in diabetic macular oedema. Eye (Lond) 19: 382-386.

47. Negi AK, Vernon SA, Lim CS, Owen-Armstrong K (2005) Intravitreal triamcinolone improves vision in eyes with chronic diabetic macular oedema refractory to laser photocoagulation. Eye 19: 747-751.

48. Lechleitner M, Koch T, Herold M, Dzien A, Hoppichler F (2000) Tumour necrosis factor-alpha plasma level in patients with type 1 diabetes mellitus and its association with glycaemic control and cardiovascular risk factors. J Intern Med 248: 67-76.

49. Jones SC, Saunders HJ, Qi W, Pollock CA (1999) Intermittent high glucose enhances cell growth and collagen synthesis in cultured human tubulointerstitial cells. Diabetologia 42: 1113-1119. 